\title{
Phenobarbital-Induced Alterations in Vitamin D Metabolism
}

\author{
T. J. Hahn, S. J. Birge, C. R. Scharp, and L. V. Avioli \\ From the Department of Medicine, Washington University School of \\ Medicine, and The Jewish Hospital of St. Louis, Missouri 63110
}

A BSTRACT The metabolic fate of intravenously injected vitamin $\mathrm{D}_{3}-1,2{ }^{3} \mathrm{H}\left(\mathrm{D}_{3}{ }^{8} \mathrm{H}\right)$ was studied in two normal individuals on chronic phenobarbital therapy. Silicic acid column chromatography of lipid-soluble plasma extracts obtained serially for $96 \mathrm{hr}$ after $\mathrm{D}_{3}{ }^{3}{ }^{3} \mathrm{H}$ injection demonstrated a decreased plasma $\mathrm{D}_{3}{ }^{-} \mathrm{H}$ halflife and increased conversion to more polar metabolites. The polar metabolites formed included several with chromatographic mobility similar to known biologically inactive vitamin $\mathrm{D}$ metabolites and one with chromatographic mobility identical to 25-hydroxycholecalciferol. Disappearance of this latter material was also accelerated. A child with rickets and a normal volunteer studied before and after a 2 wk course of phenobarbital therapy demonstrated similar alterations in $\mathrm{D}_{3}{ }^{3} \mathrm{H}$ metabolism. When liver microsomes from 3wk-old Sprague-Dawley rats treated with phenobarbital were incubated with $\mathrm{D}_{3}{ }^{8} \mathrm{H}$, polar metabolites were produced with chromatographic mobility similar to the plasma $\mathrm{D}_{3}{ }^{3} \mathrm{H}$ metabolites from phenobarbital-treated humans. Similar incubations employing 25-hydroxycholecalciferol-26,27- ${ }^{3} \mathrm{H}$ as the substrate also demonstrated an increased conversion to polar metabolites. The data suggest that the reported increased incidence of osteomalacia observed in patients on chronic anticonvulsant therapy may be the result of an accelerated conversion of vitamin $\mathrm{D}$ and its active metabolite, 25hydroxycholecalciferol, to polar metabolites by druginduced liver microsomal enzymes.

\section{INTRODUCTION}

An increased incidence of rickets in children on longterm anticonvulsant therapy was first reported in 1968 by Kruse (1). More recently, Richens and Rowe (2) have observed a striking incidence of hypocalcemia and

Dr. Avioli is a Career Research Development Awardee (7-K3-GM 22-676-05). Dr. Hahn is the recipient of Public Health Service Special Fellowship 5 PO3 CA39622-03.

Received for publication 20 January 1971 and in revised form 20 October 1971. elevations of serum alkaline phosphatase in an institutionalized adult epileptic population, the degree of hypocalcemia correlating positively with the total dosage of anticonvulsant drugs received. Simultaneously, Dent, Richens, Rowe, and Stamp (3) demonstrated that the osteomalacic bone changes in adults on long-term anticonvulsant therapy respond rapidly to vitamin D supplementation.

In a preliminary report (4) we have observed that human subjects on chronic phenobarbital therapy manifest an increased rate of disappearance of vitamin $\mathrm{D}_{3}{ }^{-}{ }^{8} \mathrm{H}$ $\left(\mathrm{D}_{3}{ }^{3} \mathrm{H}\right)^{1}$ from the plasma, and that liver microsomes from phenobarbital-treated animals are capable of rapidly converting $\mathrm{D}_{3}{ }^{3} \mathrm{H}$ to more polar metabolites in vitro. We now report that (a) patients on chronic phenobarbital therapy rapidly convert injected $\mathrm{D}_{\mathbf{s}^{-}}{ }^{3} \mathrm{H}$ to more polar metabolites, some of which are metabolically inactive; $(b)$ this increased conversion can be rapidly induced in individuals receiving a conventional dose of phenobarbital; and (c) administration of phenobarbital to rats induces increased in vitro hepatic conversion of $\mathrm{D}_{3}{ }^{8} \mathrm{H}$ and 25 -hydroxycholecalciferol- ${ }^{3} \mathrm{H}$ (25$\mathrm{OH}-\mathrm{D}_{3}-{ }^{8} \mathrm{H}$ to more polar metabolites, the increased conversion being associated with increased microsomal hydroxylase activity.

\section{METHODS}

Two normal adult females age 45 and $43 \mathrm{yr}$ (E. D. and G. D.) who had been taking phenobarbital (90-120 mg/ day) orally in divided doses for more than $1 \mathrm{yr}$, an 11 month old male infant with previously untreated rickets (C. C.) and a $30 \mathrm{yr}$ old male normal volunteer (J. H.) were used for these studies. All subjects had previously been on adequate diets containing approximately 800 IU of vitamin $\mathrm{D}$ and were studied during hospitalization after 7-10 days of adaptation to diets containing 800-1000 IU of vitamin D per day. C. C. and J. $\mathrm{H}$. were restudied after a 2 wk course of phenobarbital, $2 \mathrm{mg} / \mathrm{kg}$ per day and 1.5 $\mathrm{mg} / \mathrm{kg}$ per day, respectively, in divided oral doses. 7-9 $\mu \mathrm{Ci}$

${ }^{1}$ Abbreviations used in this paper: $\mathrm{D}_{3}{ }^{8} \mathrm{H}$, vitamin $\mathrm{D}_{3}-1,2-$ ${ }^{8} \mathrm{H}$; $\mathrm{DPH}$, diphenylhydantoin ; $25-\mathrm{OH}-\mathrm{D}_{8}, 25$-hydroxycholecalciferol; 25-OH- $\mathrm{D}_{3}{ }^{8} \mathrm{H}, 25$-hydroxycholecalciferol ${ }^{8} \mathrm{H}$. 
of a $\mathrm{D}_{3}{ }^{3} \mathrm{H}$ preparation with a specific activity of $152 \mathrm{mCi} /$ mmole (New England Nuclear Corp., Boston, Mass.) were administered i.v. in $0.7-0.8 \mathrm{ml}$ of absolute ethanol over $10-15 \mathrm{sec}$ to each subject in the fasting state. $15-20-\mathrm{ml}$ samples of heparinized blood were collected at 5,15 , and $30 \mathrm{~min}$ and at $1,2,4,8,12$, and $24 \mathrm{hr}$ after the $\mathrm{D}_{3}{ }^{3} \mathrm{H}$ injection. For the subsequent 4 days, plasma was obtained at $12 \mathrm{hr}$ intervals.

Plasma samples were subjected to combustion for determination of total ${ }^{3} \mathrm{H}$ and extracted with methanolchloroform for determination of total lipid soluble radioactivity (5). Chloroform extracts of 24-, 48-, 72-, and 96-hr plasma samples were also dried in a flash evaporator under nitrogen, the residue dissolved in Skellysolve B (a petroleum fraction boiling at $65-67^{\circ} \mathrm{C}$ ) (Skelly Oil Co., Tulsa, Okla.), applied to $50 \times 1.5 \mathrm{~cm}$ silicic acid columns and chromatographed using petroleum ether-diethyl ether-methanol elution procedures as described by Ponchon and DeLuca (6). $10-\mathrm{ml}$ fractions were collected with a flow rate of $1 \mathrm{ml} / \mathrm{min}$ and radioactivity monitored as previously described (5). The interval between initial and repeat studies in $\mathrm{C}$. $\mathrm{C}$. and $\mathrm{J} . \mathrm{H}$. was 6 and $8 \mathrm{wk}$, respectively. Extracts of $4 \mathrm{ml}$ of plasma taken just before the repeat study contained no radioactivity in C. C. and $0.04 \%$ of the injected dose confined to the peak IV region in J. $\mathrm{H}$.

Plasma $\mathrm{D}_{\mathbf{3}^{-}}{ }^{3} \mathrm{H}$ half-life as determined by column chromatography was confirmed in each subject by calculation of $\mathrm{D}_{3}{ }^{3} \mathrm{H}$ half-life determined by thin-layer chromatography of plasma samples taken at the more frequent intervals noted above (5). The peak IV fraction eluted by silicic acid chromatography of 72-hr plasma samples from the two patients on chronic phenobarbital therapy (E. D. and G. D.) was rechromatographed on a Celite partition column (JohnsManville, N. Y.) developed with the mobile phase $(20 \%$ chloroform-80\% Skellysolve B equilibrated with $90 \%$ methanol-10\% water) with $5-\mathrm{ml}$ fractions collected according to the technique of Suda et al. (7). When unlabeled 25hydroxycholecalciferol (25-OH-D $)$ (generously supplied by the Upjohn Co., Kalamazoo, Mich.) was added to the original silicic acid column for spectrophotometric identification of material migrating as $25-\mathrm{OH}-\mathrm{D}_{3}$, fractions were collected as usual, evaporated under nitrogen, made up to $5 \mathrm{ml}$ with absolute alcohol and the optical density read at $264 \mathrm{~m} \mu$ in a Beckman DU spectrophotometer (Beckman Instruments, Inc., Fullerton, Calif.).

In the animal experiments, phenobarbital $(100 \mathrm{mg} / \mathrm{kg}$ per day) dissolved in $0.50 \mathrm{ml}$ of normal saline was administered i.p. to $50 \mathrm{~g}$ immature male Sprague-Dawley rats for 5 consecutive days. The animals were anesthetized under ether and the livers perfused in vivo with iced normal saline, removed, blotted dry, weighed, and homogenized in two vol of $0.25 \mathrm{M}$ sucrose at $4^{\circ} \mathrm{C}$. Separation of liver homogenates into nuclear, mitochondrial, microsomal, and cytoplasmic fractions was accomplished by differential centrifugation according to the technique of Schneider and Hogeboom (8). The protein content of the various cell fractions obtained was determined by the method of Lowry, Rosebrough, Farr, and Randall (9). For incubation, samples of various cell fractions from treated and control animal livers were taken so as to contain equivalent amounts of protein nitrogen (equivalent to that obtained from $400 \mathrm{mg}$ of control liver).

Cell fraction samples were incubated with 3 IU of $\mathrm{D}_{3}{ }^{3} \mathrm{H}$ (519 mCi/mmole) or $3 \mathrm{IU}$ of $25-\mathrm{OH}-\mathrm{D}_{3}{ }^{3} \mathrm{H}$ (315 $\mathrm{mCi} / \mathrm{mmole}$ ) added in $0.20 \mathrm{ml}$ of methanol to achieve a final volume of $5.6 \mathrm{ml}$ containing $3.8 \mathrm{ml}$ of $0.1 \mathrm{M}$ potassium phosphate buffer ( $\mathrm{pH} 7.4$ ) with $1.60 \mathrm{ml}$ of $0.1 \mathrm{M}$ Tris buffer ( $\mathrm{pH} 7.4$ ), 0.5 mmole $\mathrm{Mg} \mathrm{Cl}$, NADPH (3 mg), glucose-6-phosphate (14 mg) and glucose-6-phosphate-dehydrogenase $(5 \mathrm{KU})$. Incubation was carried out in a $\begin{array}{lllllll}\text { Dubnoff metabolic shaker under a } 95 \% & \mathrm{O}_{2} / 5 \% & \mathrm{CO}_{2} & \text { gas }\end{array}$ phase according to the technique of Conney and Klutch (10). The reaction was terminated at $60 \mathrm{~min}$ by the addition of 5 vol of a solution of methanol-chloroform $(\mathrm{V}: \mathrm{V}$, $2: 1)$ and the mixture homogenized in a Potter-Elvehjem homogenizer fitted with a Teflon pestle. The aqueous- and lipid-soluble phases were separated and portions of each phase subjected to lipid scintillation counting as previously described (5). The remainder of the lipid phase was evaporated to dryness under a stream of nitrogen and redissolved in Skellysolve B. The products of the $\mathrm{D}_{\mathbf{8}}{ }^{8} \mathrm{H}$ incubation were applied to silicic acid columns as described above. The products of the $25-\mathrm{OH}-\mathrm{D}_{\mathbf{3}}{ }^{-} \mathrm{H}$ incubation were portioned onto fiberglass-backed silica gel thin-layer medium (Gelman type SG; Gelman Instrument Company, Ann Arbor. Mich.) and separated into $25-\mathrm{OH}-\mathrm{D}_{8}{ }^{-} \mathrm{H}$ and more polar metabolites with a solvent system of hexane/acetone $(\mathrm{V}: \mathrm{V}, 85: 15)$. When hexobarbital was employed as a substrate, it was added to the flask in a volume of $2 \mathrm{ml}$ of $0.2 \mathrm{M}$ potassium phosphate buffer $(0.5 \mu$ mole hexobarbital/ $1 \mathrm{ml}$ buffer). Hexobarbital oxidation was determined by the method of Cooper and Brodie (11).

\section{RESULTS}

Disappearance and metabolic fate of vitamin $D_{3}$ in plasma. The plasma half-life of $\mathrm{D}_{3}{ }^{-}{ }^{8} \mathrm{H}$ as determined by silicic acid column chromatography in two otherwise normal adults (E. D. and G. D.) on chronic phenobarbital therapy $(1.3-1.5 \mathrm{mg} / \mathrm{kg}$ per day) was significantly decreased when compared to a group of 12 normal adults ( 7 males and 5 females, aged 26-48 yr) not on phenobarbital studied under similar conditions (Table I). Moreover, administration of phenobarbital orally for 2 wk to C. C., a child with previously untreated rickets $(1.5 \mathrm{mg} / \mathrm{kg}$ per day), and J. H., a normal adult volunteer ( $2 \mathrm{mg} / \mathrm{kg}$ per day), resulted in

TABLE I

Effect of Phenobarbital Treatment on Plasma Half-Life of $D_{3^{-}}{ }^{3} \mathrm{H}$

\begin{tabular}{lcc}
\hline & Control & Phenobarbital \\
\hline & $h r$ & $h r$ \\
C. C. (rickets) & 18.1 & 10.0 \\
J. H. (normal adult) & 28.9 & 17.5 \\
G. D. (normal adult) & & 13.5 \\
E. D. (normal adult) & & 13.0 \\
Normal adult controls & & \\
$\quad(12$ subjects) & $26.1 \pm 1.3$ &
\end{tabular}

Half-lives were calculated by analysis of semilogarithmic plots of plasma $\mathrm{D}_{3}{ }^{-3} \mathrm{H}$ (expressed as per cent administered dose) disappearance with time determined by silicic acid column chromatography for the interval beginning at $12 \mathrm{hr}$ and terminating $96 \mathrm{hr}$ after $\mathrm{D}_{3}{ }^{3} \mathrm{H}$ administration. Control values are given as mean \pm 1 SEM. 


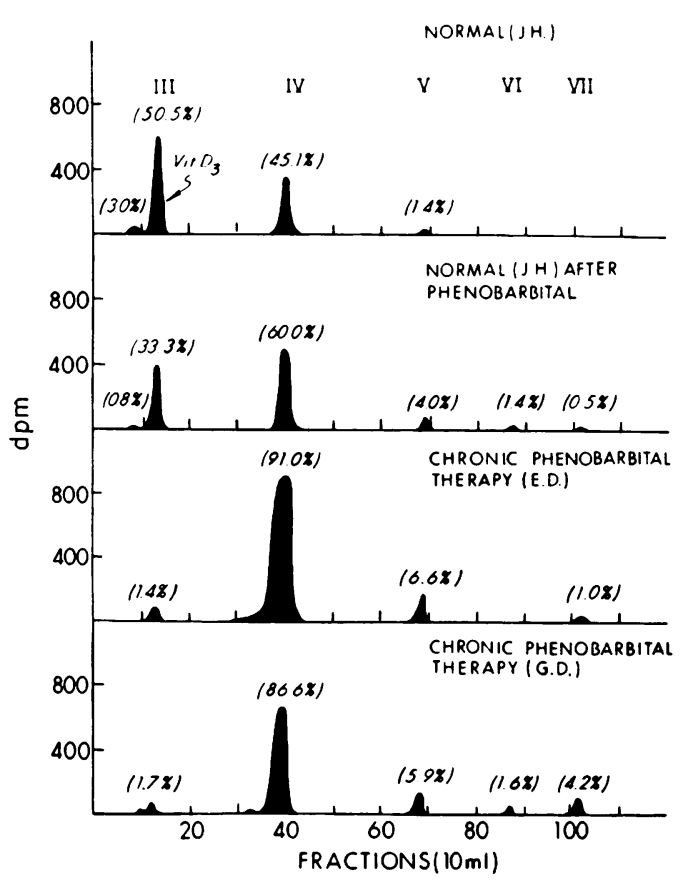

FIGURE 1 Column chromatographic profile of chloroform extracts of $4 \mathrm{ml}$ of plasma obtained $72 \mathrm{hr}$ after an i.v. dose of $\mathrm{D}_{3}{ }^{8} \mathrm{H}$ in a normal subject (J. H.) before and after a 2 wk course of phenobarbital, and two subjects on chronic phenobarbital therapy (E. D. and G. D.). The chloroform extracts were chromatographed on silicic acid columns using the gradient elution technique of Ponchon and DeLuca (6).

a similar decrease in $\mathrm{D}_{3}{ }^{3} \mathrm{H}$ plasma half-life. Silicic acid column profiles of the plasma lipid soluble radioactivity $72 \mathrm{hr}$ after injection of $\mathrm{D}_{3}{ }^{-} \mathrm{H}$ are illustrated in Fig. 1 .

The material in peak III has been isolated previously from human plasma after $\mathrm{D}_{3}{ }^{8} \mathrm{H}$ administration and identified as unaltered vitamin $\mathrm{D}_{3}$ with potent in vivo antirachitic activity (5). In the multigradient chromatographic system employed in this study, peak IV ordinarily represents $25-\mathrm{OH}-\mathrm{D}_{3}$, the biologically active metabolite of vitamin D (12). Further confirmation of the chromatographic identity of peak IV as $25-\mathrm{OH}-\mathrm{D}_{3}$ in these studies was obtained by adding $0.50 \mathrm{mg}$ of pure $25-\mathrm{OH}-\mathrm{D}_{3}$ to 72 -hr plasma extracts from E. D. and G. D. and applying to silicic acid columns. Fractions were collected as usual, and samples taken for measurements of optical density at $264 \mathrm{~m} \mu$, as well as radioactivity by liquid scintillation counting. The optical density of $25-\mathrm{OH}-\mathrm{D}_{3}$ at $264 \mathrm{~m} \mu$ in each case coincided exactly with the peak IV radioactivity. Additional confirmation was obtained by isolating the peak IV metabolite from silicic acid columns and rechromatographing on Celite partition columns (7). In each instance, a single peak of radioactivity was obtained which was exactly coincident with $25-\mathrm{OH}-\mathrm{D}_{3}$ as determined by optical density measurements.

Normally, $25-\mathrm{OH}-\mathrm{D}_{3}$ is derived from vitamin $\mathrm{D}_{3}$ by hydroxylation in the liver, possibly by a specific mitochondrial hydroxylase $(13,14)$. Peak $\mathrm{V}$ is ordinarily comprised of at least three biologically active vitamin D metabolites, 21, 25-, 25, 26-, and 1,25-dihydroxy cholecalciferol as well as several unidentified components $(7,15-17)$. The identity of peaks VI and VII is presently unknown but they have been demonstrated to be biologically inactive (12).

The chromatographic profile of $\mathrm{D}_{s}{ }^{-} \mathrm{H}$ metabolites in the 72-hr control plasma samples from J. H. (normal subject) is typical of the normal column profile (Fig. 1 , top). During the second $\mathrm{D}_{3}{ }^{3} \mathrm{H}$ study performed after 2 wk of phenobarbital therapy, the percentage of radioactivity in J. H.'s $72 \mathrm{hr}$ plasma migrating as $\mathrm{D}_{3}{ }^{8}{ }^{8} \mathrm{H}$ was decreased and the percentage migrating as 25 $\mathrm{OH}-\mathrm{D}_{3}{ }^{3} \mathrm{H}$ (peak IV) and more polar metabolites (peak $\mathrm{V}, \mathrm{VI}, \mathrm{VII}$ ) was increased. In the two normal subjects on long-term phenobarbital therapy, the changes were even more striking (Table II).

The time course of disappearance of $\mathrm{D}_{3}{ }^{3} \mathrm{H}$ and appearance of $25-\mathrm{OH}-\mathrm{D}_{3}{ }^{3} \mathrm{H}$ and more polar metabolites in control and phenobarbital-treated subjects is illustrated in Figs. 2 and 3. The disappearance of $D_{s}{ }^{-8} \mathrm{H}$ and the appearance of $25-\mathrm{OH}-\mathrm{D}_{3}{ }^{3} \mathrm{H}$ and peaks V-VII were markedly accelerated in the phenobarbital-treated subjects. The generated $25-\mathrm{OH}-\mathrm{D}_{3}{ }^{-}{ }^{3} \mathrm{H}$ peak increased with time, reaching maximal value by $24 \mathrm{hr}$ (1.8 times the $\mathrm{D}_{3}{ }^{-} \mathrm{H}$ half-life) in the phenobarbital-treated subjects and then began to fall off rapidly. In contrast, the level of the 25-OH-D 3 peak was still rising after $96 \mathrm{hr}$ (3.5 times the $\mathrm{D}_{3}{ }^{8} \mathrm{H}$ half-life) in control subjects. The relatively earlier onset of decay of the 25$\mathrm{OH}-\mathrm{D}_{3}-{ }^{3} \mathrm{H}$ peak suggests increased metabolism as well as more rapid appearance of this metabolite in phenobarbital-treated subjects.

The portion of plasma radioactivity occurring as aqueous-soluble metabolites was determined by subtracting plasma lipid-soluble radioactivity from total

TABLE II

Distribution of Lipid-Soluble Radioactivity in 72 Hr Plasma Sample

\begin{tabular}{lcccccc}
\hline & III* & IV* & V* & VI* & VII* \\
\hline & \multicolumn{7}{c}{ \% } & of injected radioactivity \\
J. H. (control) & 1.46 & 1.31 & 0.04 & 0 & 0 \\
J. H. (after phenobarbital) & 1.27 & 2.28 & 0.15 & 0.05 & 0.02 \\
E. D. (chronic phenobarbital) & 0.13 & 8.55 & 0.56 & 0 & 0.09 \\
G. D. (chronic phenobarbital) & 0.14 & 7.27 & 0.50 & 0.13 & 0.35
\end{tabular}

* Chromatographic fractions as designated by Ponchon and DeLuca (11) and designated in Figs, 1 and 4. 


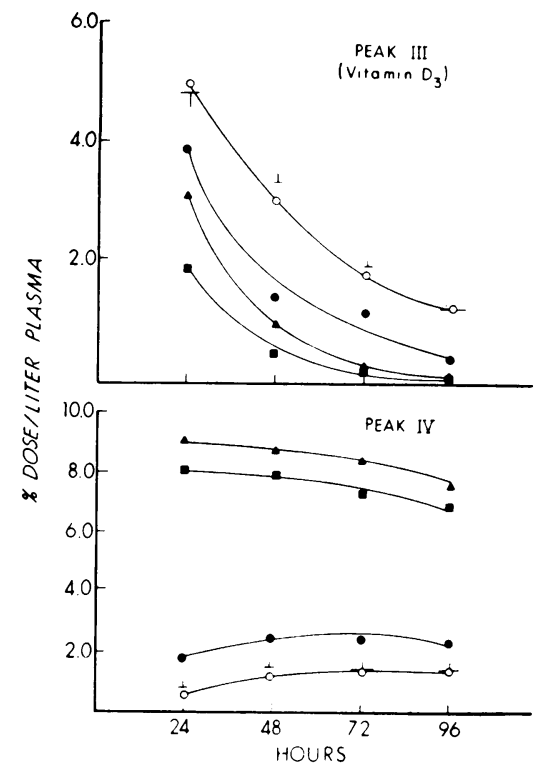

FIgURE 2 Time course of plasma vitamin $\mathrm{D}_{3}$ disappearance and peas IV appearance in three normal controls $(\perp$, mean ISEM), J. H. control period (O), J. H. after phenobarbital $(\boldsymbol{\bullet})$, and two subjects, E. D. ( $\boldsymbol{\Delta})$ and G. D. ( $\boldsymbol{(})$, on chronic phenobarbital therapy.

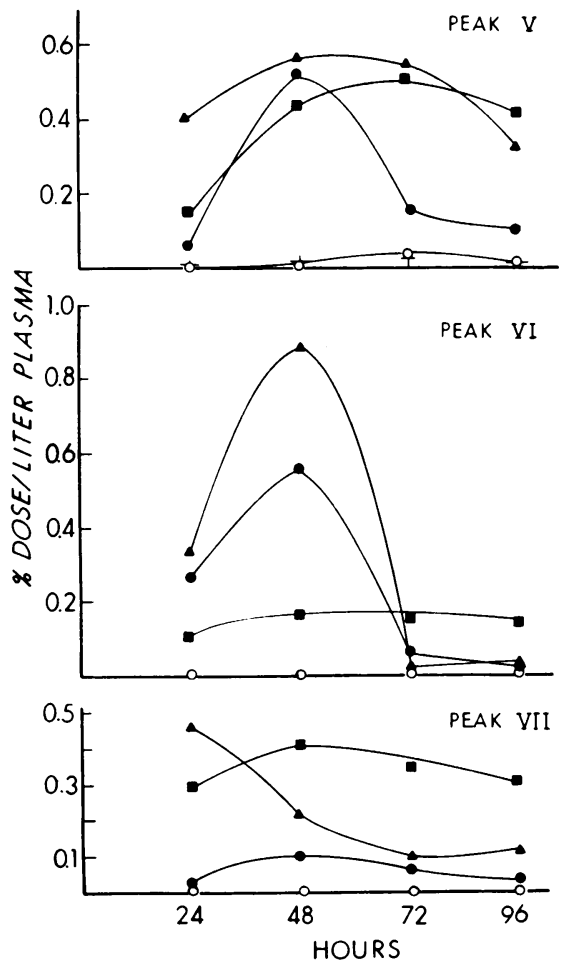

Figure 3 Time course of appearance of peaks V, VI, and VII in three normal controls $(\perp$, mean \pm SEM $), J . H$. control period $(O)$, J. H. after phenobarbital $(\bullet)$, and two subjects, E. D. (A) and G. D. ( $\boldsymbol{\square})$, on chronic phenobarbital therapy.

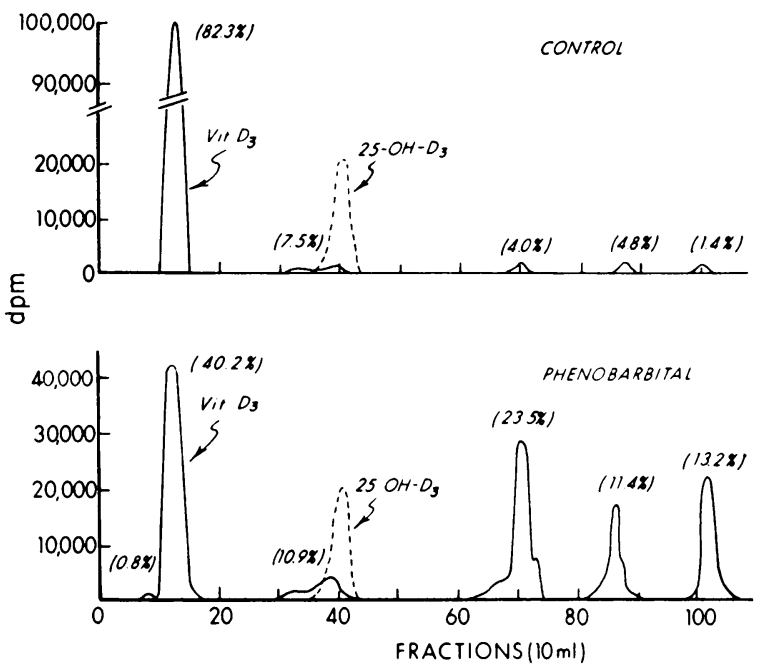

Figure 4 Column chromatographic profiles of chloroform extracts of reaction mixtures from incubations of $\mathrm{D}_{3}-{ }^{8} \mathrm{H}$ with microsomes from control and phenobarbital-treated rats. $3 \mathrm{IU}$ of $\mathrm{D}_{3}{ }^{8} \mathrm{H}$ were incubated aerobically for $60 \mathrm{~min}$ at $37^{\circ}$ with $11 \mathrm{mg}$ of microsomal protein from control and phenobarbital-treated animals in the presence of a NADPHgenerating system (9). The dashed lines indicate the chromatographic position of added (26-27) ${ }^{8} \mathrm{H}-25$-hydroxycholecalciferol. Chromatographic techniques were identical to those described in Fig. 1.

plasma radioactivity determined by combustion. The per cent plasma aqueous-soluble metabolites for J. $\mathrm{H}$. and C. C. after phenobarbital and E. D. and G. D. did not vary significantly from the normal control values of $25.3 \pm 3.7,19.6 \pm 5,22.3 \pm 3.8$, and $24.0 \pm 2.3$ at $24,48,72$, and $96 \mathrm{hr}$, respectively.

In vitro metabolism of $D_{s^{-}}{ }^{3} \mathrm{H}$ and 25-OH- $D_{s^{-}}{ }^{3} \mathrm{H}$ hepatic cell fractions. Subcellular components obtained by differential centrifugation from homogenates of livers from 3-wk old male Sprague-Dawley rats treated with

\section{TABLE III}

Effect of Phenobarbital Treatment on Hepatic Microsomal Metabolism of $D_{3}{ }^{3} \mathrm{H}$

\begin{tabular}{lccc}
\hline & $\begin{array}{c}\text { Unaltered } \\
\mathrm{D}^{-3} \mathrm{H}\end{array}$ & $\begin{array}{c}\text { Water-soluble } \\
\text { metabolites }\end{array}$ & $\begin{array}{c}\text { Hexobarbital } \\
\text { oxidized }\end{array}$ \\
\hline & $\begin{array}{c}\text { \% of lipid-soluble } \\
\text { radioactivity }\end{array}$ & $\begin{array}{c}\text { \% of total } \\
\text { radioactivity }\end{array}$ & nmoles \\
Media control & $94.9 \pm 0.3$ & $0.2 \pm 0.2$ & - \\
Control & $79.0 \pm 2.8$ & $2.1 \pm 0.8$ & $75 \pm 6$ \\
Phenobarbital & $45.2 \pm 3.6$ & $7.4 \pm 1.2$ & $585 \pm 16$ \\
\hline
\end{tabular}

Values represent the mean \pm SEM of at least three determinations. Incubation conditions were identical to those described in Fig. 4. Media control values were obtained by incubating $\mathrm{D}_{3}{ }^{-3} \mathrm{H}$ in the absence of microsomes. Watersoluble metabolites were determined by previously described techniques (5). Hexobarbital (1000 nmoles) was added in parallel incubations to flasks containing $11 \mathrm{mg}$ of microsomal protein from control and phenobarbitaltreated animals. 
TABLE IV

Effect of Phenobarbital Treatment on Hepatic Microsomal Metabolism of $25-\mathrm{OH}-\mathrm{D}_{3}{ }^{3} \mathrm{H}$

\begin{tabular}{lccc}
\hline & $\begin{array}{c}\text { Unaltered } \\
25-\mathrm{OH}-\mathrm{D}^{-}{ }^{-} \mathrm{H}\end{array}$ & $\begin{array}{c}\text { Water-soluble } \\
\text { metabolites }\end{array}$ & $\begin{array}{c}\text { Hexobarbital } \\
\text { oxidized }\end{array}$ \\
\hline $\begin{array}{c}\text { \% of lipid-soluble } \\
\text { radioactivity }\end{array}$ & $\begin{array}{c}\text { \% of total } \\
\text { radioactivity }\end{array}$ & nmoles \\
Medial control & $95.6 \pm 0.6$ & $0.3 \pm 0.2$ & - \\
Control & $83.8 \pm 1.4$ & $2.7 \pm 0.4$ & $52 \pm 3$ \\
Phenobarbital & $61.4 \pm 1.9$ & $8.9 \pm 1.1$ & $528 \pm 21$ \\
\hline
\end{tabular}

Values represent the mean \pm SEM of at least five determinations. Incubation conditions were identical to those described in Table III with the substitution of $25-\mathrm{OH}-\mathrm{D}_{3}-{ }^{-3} \mathrm{H}$ as the substance.

phenobarbital were incubated with $\mathrm{D}_{3}{ }^{3}{ }^{3} \mathrm{H}$ and the results compared with incubations with equivalent amounts of protein nitrogen from corresponding subcellular fractions of control animals. Whereas microsomes from control animal livers had a minimal effect on $\mathrm{D}_{3}{ }^{8} \mathrm{H}$ at the concentrations employed, hepatic microsomes from phenobarbital-treated animals catalyzed an accelerated conversion of $\mathrm{D}_{3}{ }^{-} \mathrm{H}$ to lipid-soluble products which were more polar than $25-\mathrm{OH}-\mathrm{D}_{3}{ }^{3} \mathrm{H}$ (Fig. 4). Additionally, there was a $250 \%$ increase in total watersoluble vitamin $\mathrm{D}_{3}$ metabolites. These changes were associated with increased microsomal oxidation of hexobarbital (Table III). Similarly, whereas $25-\mathrm{OH}-\mathrm{D}_{3}{ }^{8} \mathrm{H}$ was only slightly metabolized by the liver microsomes obtained from control animals, liver microsomes obtained from phenobarbital-treated animals increased conversion of $25-\mathrm{OH}-\mathrm{D}_{3}{ }^{-}{ }^{8} \mathrm{H}$ to more polar metabolites (Table IV). Incubation of either $\mathrm{D}_{3}{ }^{3} \mathrm{H}$ or $25-\mathrm{OH}-\mathrm{D}_{3}{ }^{-} \mathrm{H}$ with nuclear, mitochondrial, or cytoplasmic hepatic cell fractions from phenobarbital-treated animals demonstrated no difference from incubations with similar fractions from control animals.

The metabolic products obtained from $\mathrm{D}_{3}{ }^{-14} \mathrm{C}$ incubated in vitro with microsomes from phenobarbitaltreated rats were cochromatographed on silicic acid columns with the $\mathrm{D}_{3}{ }^{3} \mathrm{H}$ metabolites from the plasma of the patients on chronic phenobarbital therapy (Fig. 5). $\mathrm{D}_{3}{ }^{14} \mathrm{C}$ metabolites derived from microsome incubation had a mobility almost identical to the plasma metabolites obtained from the human subjects on phenobarbital.

\section{DISCUSSION}

The demonstration of accelerated metabolism of vitamin $D_{3}$ in subjects on phenobarbital therapy would provide a rational basis for the reported increased incidence of osteomalacia in individuals on chronic anticonvulsant therapy $(1,2)$. The results of the present experiments suggest that this accelerated metabolism is the result of drug-stimulated increases in hepatic microsomal activity.

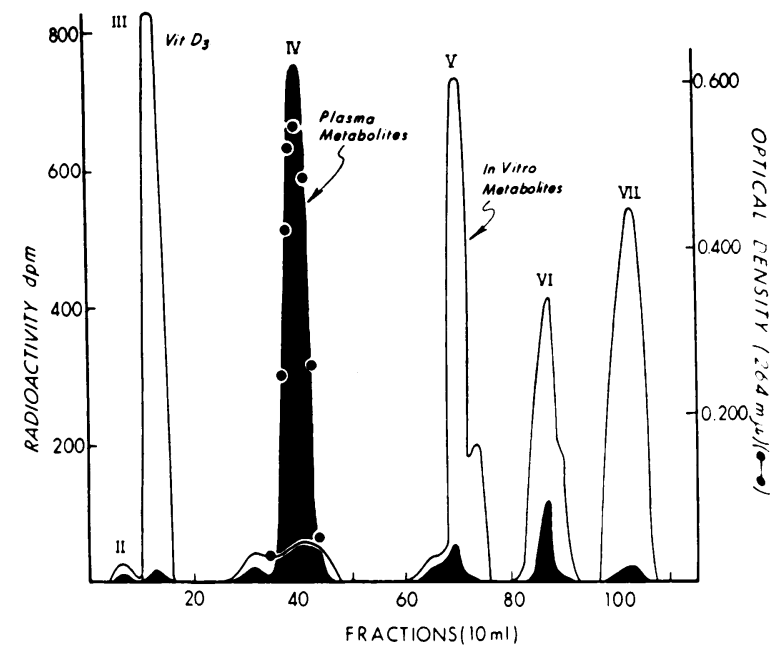

Figure 5 Cochromatography of plasma $\mathrm{D}{ }^{-}{ }^{3} \mathrm{H}$ metabolites from a patient (E. D.) on chronic phenobarbital therapy (closed figures) with metabolic products obtained from in vitro incubation of $\mathrm{D}_{3}{ }^{14} \mathrm{C}$ with microsomes from phenobarbital-treated rats (open figures). The optical density of pure $25-\mathrm{OH}-\mathrm{D}_{3}(\bullet)$ added to the patient plasma extract is indicated on the scale at right. The patient plasma was obtained $72 \mathrm{hr}$ after the i.v. injection of $\mathrm{D}_{3}{ }^{-} \mathrm{H}$. Microsomal incubation conditions were identical to those described for Fig. 3. Chromatographic techniques were identical to those described for Fig. 1.

It has been well established that the induction of increased liver microsomal enzyme activity by phenobarbital results in decreased in vivo biologic activity of steroid compounds. Levin, Welch, and Conney demonstrated that pretreating immature female rats with phenobarbital in doses as low as $2 \mathrm{mg} / \mathrm{kg}$ per day diminished the uterotrophic response to administered estradiol or estrone, decreased the uterine concentration of injected tritiated estrogens and increased production of polar estrogen metabolites $(18,19)$. Also, phenobarbital treatment has been demonstrated to decrease the seminal vesicle-stimulating effect of androgens (20) and to diminish the effect of progesterone in association with increased hepatic hydroxylation and decreased total body accumulation of the steroid and its metabolites (21).

Similarly, induction of liver microsomal enzyme activity with diphenylhydantoin (DPH) has been demonstrated to have important clinical effects on steroid metabolism in humans. Werk, Sholitan, and Olinger (22) demonstrated that DPH therapy sharply decreased plasma cortisol levels, increased urinary excretion of 6-OH cortisol and resulted in clinical improvement in patients with Cushing's syndrome. More recently, Choi, Thrasher, Werk, Sholitan, and Olinger (23) have reported that DPH administration in patients with various disorders resulted in a decreased plasma cortisol half- 
life, with a compensatory increase in cortisol secretory rate. Additionally, Jubiz and coworkers (24) have reported decreased effectiveness of dexamethasone in suppressing morning plasma cortisol levels in association with increased urinary and biliary excretion of conjugated dexamethasone or its metabolites in individuals on DPH therapy.

Similarities between the drug and steroid hydroxylases in hepatic microsomes have led to the suggestion that drugs and steroids are substrates for the same hepatic P-450 enzyme system (25). Hence, agents which increase the activity of hepatic drug-metabolizing enzymes could be expected to increase hydroxylation of steroid compounds as well. The drug-induced microsomal enzymes hydroxylate steroids predominantly at the $6 \beta, 7 \alpha$, and $16 \alpha$ positions (26). Thus, the resultant steroid metabolites tend to be more polar than their parent compound. Since vitamin $\mathrm{D}_{3}$ and $25-\mathrm{OH}-\mathrm{D}_{3}$ are structurally similar to the steroid hormones and are readily accumulated by the liver $(27,28)$, these compounds might well be expected to be metabolized to more polar products by the hepatic P-450 system. Although the polar lipid-soluble $\mathrm{D}_{3^{-}}{ }^{3} \mathrm{H}$ metabolites occurring in increased proportion in phenobarbital-treated humans are as yet unidentified, their chromatographic similarity to metabolites produced by phenobarbitalinduced rat liver microsomal enzymes makes it likely that some of the human plasma metabolites are the result of increased liver microsomal activity. There are, however, quantitative differences between the metabolites produced in the in vitro $\mathrm{D}_{3}{ }^{3} \mathrm{H}$ studies and those noted in the plasma of patients treated with phenobarbital. Whereas the major portion of the radioactivity in human $72-\mathrm{hr}$ plasma samples occurred as $25-\mathrm{OH}-\mathrm{D}_{\boldsymbol{z}}$, peaks V, VI, and VII were the more prominent $\mathrm{D}_{\mathbf{8}}{ }^{8} \mathrm{H}$ metabolites in the microsomal incubations.

The explanation for the observed differences in vivo and in vitro metabolites is not entirely clear. Since it has been reported that the hepatic vitamin $D_{3}$ 25-hydroxylase is of mitochondrial origin, it is not surprising that the microsomal incubations in these studies did not produce significant amounts of $25-\mathrm{OH}-\mathrm{D}_{8}$. On the other hand, mitochondrial fractions from phenobarbital-treated animals were likewise not found to produce increased amounts of $25-\mathrm{OH}-\mathrm{D}_{3}$. It is possible that differences between patterns of plasma and intracellular metabolites or differences between in vivo and in vitro pathways might account for the differences between in vivo and in vitro metabolite patterns. A more likely explanation relates to the fact that, due to accelerated microsomal metabolism, it would be anticipated that body stores of vitamin $\mathrm{D}_{3}$ and 25-OH-D would gradually become depleted in individuals on chronic phenobarbital therapy. Since it has been demon- strated both in rats (29) and humans (30) that the fraction of an injected tracer dose of $\mathrm{D}_{3}{ }^{8} \mathrm{H}$ converted to $25-\mathrm{OH}-\mathrm{D}_{3}{ }^{8} \mathrm{H}$ varies inversely with body vitamin $\mathrm{D}$ pool size, an increased proportion of injected $\mathrm{D}_{\mathbf{s}}{ }^{8} \mathrm{H}$ appearing as $25-\mathrm{OH}-\mathrm{D}_{3}{ }^{2} \mathrm{H}$ in phenobarbital-treated subjects would be expected if these individuals have decreased levels of vitamin $\mathrm{D}_{3}$ and 25-OH-Ds. Our recent observations that plasma levels of $25-\mathrm{OH}-\mathrm{D}_{3}$ measured by competitive protein-binding assay (31) are depressed in individuals on chronic phenobarbital therapy ${ }^{2}$ support this hypothesis.

It is also theoretically possible that displacement of $\mathrm{D}_{3}{ }^{8} \mathrm{H}$ or $25-\mathrm{OH}-\mathrm{D}_{3}{ }^{8} \mathrm{H}$ from plasma-binding protein by phenobarbital might account for an increased plasma disappearance rate. This is quite unlikely, however, since phenobarbital in concentrations of $500 \mu \mathrm{g} / \mathrm{ml}$, approximately 50 times the usual therapeutic plasma levels, does not displace $25-\mathrm{OH}-\mathrm{D}_{3}{ }^{8} \mathrm{H}$ from partially purified 25-OH-Ds plasma-binding protein in vitro. ${ }^{2}$

Decreased vitamin $\mathrm{D}$ effect in individuals receiving agents which induce hepatic microsomal enzymes could result either from a decreased biologic activity of the polar vitamin $\mathrm{D}$ metabolites or increased excretion of these more polar compounds. Decreased biologic activity of the vitamin D metabolites might play some role since the appearance of inactive peak VI and VII $\mathrm{D}_{3}{ }^{3} \mathrm{H}$ metabolites was increased both in human subjects on phenobarbital and in vitro incubations of $\mathrm{D}_{3}{ }^{8} \mathrm{H}$ with microsomes from phenobarbital-treated rats. Additionally, it is unlikely that the in vitro peak $\mathrm{V}$ metabolite represents any of the known biologically active vitamin $\mathrm{D}_{3}$ metabolites with peak $\mathrm{V}$ mobility, since evidence to date indicates that 1,25-dihydroxycholecalciferol is derived from $25-\mathrm{OH}-\mathrm{D}_{3}$ exclusively in the kidney (32), while there is no evidence to suggest that either 21,25 -, or 25,26 -dihydroxycholecalciferol is produced by the liver. ${ }^{8}$ On the other hand, induction of hepatic drug-metabolizing enzymes by $\mathrm{DPH}$ is associated with increased urinary and biliary excretion of polar steroid metabolites (24). In normal humans, a fraction of i.v. injected $\mathrm{D}_{3}{ }^{8} \mathrm{H}$ appears rapidly in the bile and urine as water-soluble metabolites, a major portion of which are glucuronides and acid conjugates (5). Hence, increased production of polar vitamin D metabolites due to increased hydroxylation and/or glucuronidation might well result in increased biliary and urinary loss of vitamin D.

It is of interest that clinical osteomalacia can be demonstrated in relatively large proportions of epileptics on chronic anticonvulsant therapy $(1,2)$, while clinical evidence of deficiencies of other steroids such

\footnotetext{
${ }^{2}$ Haddad, J. G., and T. J. Hahn. Unpublished observations.

${ }^{3}$ H. F. DeLuca. Personal communication.
} 
as cortisol or estrogen are apparently not commonly observed in this group. This would perhaps be expected, since endogenous levels of cortisol, estrogen, and androgens are known to be regulated through pituitary feedback mechanisms, whereas, to date, there is only fragmentary evidence that production of the active 25-OH-D $\mathrm{D}_{\mathbf{3}}$ metabolite may be subject to hepatic feedback regulation (14). The demonstration that anticonvulsant-induced osteomalacia responds rapidly to vitamin D therapy $(1,2)$ suggests, however, that increasing the endogenous level of vitamin D by exogenous supplementation is effective in correcting the drug-induced deficiency. A corollary of the observed decreased effectiveness of normal dietary vitamin $D$ in individuals on chronic anticonvulsant therapy is the anticipation that increased hepatic drug-metabolizing activity would impart resistance to exogenously administered vitamin D. In this regard, there is preliminary evidence that phenobarbital pretreatment may protect rats from vitamin D-induced hypercalcemia (3). This raises the possibility that treatment with a nonhypnotic barbituate such as phenylbarbital (33) might be effective, relatively nontoxic therapy for vitamin $\mathrm{D}$ intoxication. Additionally, the resistance to vitamin D occasionally seen in individuals with postsurgical hypoparathyroidism on phenobarbital therapy may be attributable to induction of hepatic drug-metabolizing enzymes.

The immediate implication of these studies is that care should be exercised in interpreting $\mathrm{D}_{3}{ }^{8} \mathrm{H}$ kinetic data in persons receiving medications known to induce hepatic drug-metabolizing enzymes. Additionally, since the hepatic drug-metabolizing systems are stimulated by a wide variety of commonly used agents, including barbituates, methylphenylethylhydantoin, DPH, meprobamate, chlordiazepoxide, and chlorpromazine (34), among others, the potential for altered vitamin D metabolism in many clinical situations is apparent. Therefore, patients on high doses of drugs known to stimulate hepatic drug-metabolizing enzymes, especially those individuals with marginal dietary intake or diseases predisposing to vitamin $\mathrm{D}$ malabsorption, should be carefully evaluated for evidence of vitamin $\mathrm{D}$ deficiency.

\section{ACKNOWLEDGMENTS}

This work was supported by Public Health Service Grants AM-11674 and Clinical Research Grant FR-36 from the General Clinical Research Center Branch, Division of Research Facilities and Resources.

\section{REFERENCES}

1. Kruse, R. 1968. Osteopathien bei antiepileptischer Langzeittherapie. Monatsschr. Kinderheilk. 116: 378.

2. Richens, A., and D. J. F. Rowe. 1970. Disturbance of calcium metabolism by anticonvulsant drugs. Brit. Med. $J .4: 73$.
3. Dent, C. E., A. Richens, D. J. F. Rowe, and T. C. B. Stamp. 1970. Osteomalacia with long-term anticonvulsant therapy in epilepsy. Brit. Med. J. 4: 69.

4. Hahn, T. J., J. G. Haddad, S. J. Birge, and L. V. Avioli. 1970. Phenobarbital-induced acceleration of vitamin D metabolism. J. Clin. Invest. 49: 39a. (Abstr.)

5. Avioli, L. V., S. W. Lee, J. E. McDonald, J. Lund, and H. F. DeLuca. 1967. Metabolism of vitamin $\mathrm{D}_{\mathbf{8}}{ }^{3} \mathrm{H}$ in human subjects: distribution in blood, bile, feces, and urine. J. Clin. Invest. 46: 983.

6. Ponchon, G., and H. F. DeLuca. 1969. The role of the liver in the metabolism of vitamin D. J. Clin. Invest. 48: 1273.

7. Suda, T., H. F. DeLuca, H. K. Shnoes, G. Ponchon, Y. Tanaka, and M. F. Holick. 1970. 21,25-dihydroxycholecalciferol. A metabolite of vitamin $\mathrm{D}_{3}$ preferentially active on bone. Biochemistry. 9: 2917.

8. Schneider, W. C., and G. H. Hogeboom. 1950. Intracellular distribution of enzymes. V. Further studies on distribution of cytochrome $\mathrm{C}$ in rat liver. J. Biochem. 183: 1223 .

9. Lowry, O. H., N. J. Rosebrough, A. L. Farr, and G. A. Randall. 1951. Protein measurement with the folinphenol reagent. J. Biochem. 193: 265.

10. Conney, A. H., and A. Klutch. 1963. Increased activity of androgen hydroxylases in liver microsomes of rats treated with phenobarbital and other drugs. J. Biochem. 238: 1611 .

11. Cooper, J. R., and B. B. Brodie. 1955. The enzymatic metabolism of hexobarbital. J. Pharmacol. 114: 409.

12. Ponchon, G., and H. F. DeLuca. 1969. Metabolites of vitamin $\mathrm{D}_{3}$ and their biologic activity. J. Nutr. 99: 157.

13. Horsting, M. N., and H. F. DeLuca. 1969. In vitro production of 25-hydroxy-cholecalciferol. Biochem. Biophys. Res. Comm. 36: 251.

14. DeLuca, H. F. 1970. Vitamin D metabolism and its relationship to the familial hypophosphatemia. Birth Defects Orig. Artic. Ser. 6 (No. 3) : 26.

15. Haussler, M. R., J. F. Myrtle, and A. W. Norman. 1968. The association of a metabolite of vitamin $D_{3}$ with intestinal mucosa chromatin in vivo. J. Biochem. 243: 4055.

16. Suda, C., H. F. Deluca, H. K. Schnoes, G. Ponchon, Y. Tanaka, and M. F. Holick. 1970. 25,26-dihydroxycholecalciferol, a metabolite of vitamin $\mathrm{D}_{3}$ with intestinal calcium transport activity. Biochemistry. 9: 4476.

17. Holick, M. F., and H. F. DeLuca. 1971. A new chromatographic system for vitamin $\mathrm{D}_{3}$ and its metabolites: resolution of a new vitamin $\mathrm{D}_{3}$ metabolite. J. Lipid Res. $12: 460$.

18. Levin, W., R. M. Welch, and A. H. Conney. 1968. Effect of phenobarbital and other drugs on the metabolism and uterotrophic action of estradiol-17B and estrone. J. Pharmacol. 159: 362.

19. Levin, W., R. M. Welch, and A. H. Conney. 1967. Effect of chronic phenobarbital treatment on the liver microsomal metabolism and uterotrophic action of estradiol-17B. Endocrinology. 80: 135.

20. Kuntzman, R. 1969. Drugs and enzyme induction. Ann. Rev. Pharmacol. 9: 21.

21. Conney, A. H., M. Jacobson, K. Schneidman, and R. Kuntzman. 1966. Decreased central depressant effect of progesterone and other steroids in rats pretreated with drugs and insecticides. J. Pharmacol. 154: 310 . 
22. Werk, E. E., Jr., L. J. Sholiton, and C. P. Olinger. 1966. Amelioration of nontumorous Cushing's syndrome by diphenylhydantoin. Androgens Norm. Pathol. Cond. Proc. Symp. Steroid Horm. 2nd. 1: 301.

23. Choi, Y., K. Thrasher, E. E. Werk, Jr., L. J. Sholitan, and C. Olinger. 1971. Effect of diphenylhydantoin on cortisol kinetics in humans. J. Pharmacol. 176: 27.

24. Jubiz, W., A. W. Meikle, R. A. Levinson, S. Mizutani, C. D. West, and F. H. Tyler. 1970. Effect of diphenylhydantoin on the metabolism of dexamethasone. N. Engl. J. Med. 283: 11 .

25. Kuntzman, R., M. Jacobson, K. Schneidman, and A. H. Conney. 1964. Similarities between oxidative drug metabolizing enzymes and steroid hydroxylases in liver microsomes. J. Pharmacol. 146: 280.

26. Conney, A. H., K. Schneidman, M. Jacobson, and R. Kuntzman. 1965. Drug-induced changes in steroid metabolism. Ann. N. Y. Acad. Sci. 123: 98.

27. Ponchon, G., and H. F. DeLuca. 1969. The role of the liver in the metabolism of vitamin D. J. Clin. Invest. 48: 1273 .
28. Cousins, R. J., H. F. DeLuca, and R. W. Gray. 1970. Metabolism of 25-hydroxycholecalciferol in target and nontarget tissues. Biochemistry. 9: 3649.

29. Lund, J., and H. F. DeLuca. 1966. Biologically active metabolites of vitamin $\mathrm{D}_{3}$ from bone, liver, and blood serum. J. Lipid Res. 7 : 739.

30. Mawer, E. B., G. A. Lumb, K. Schaefer, and S. W. Stanbury. 1971. The metabolism of isotopically labelled vitamin $\mathrm{D}_{3}$ in man. I. The influence of the state of vitamin D nutrition. Clin. Sci. 40: 49.

31. Haddad, J. G., Jr., and K. J. Chyu. 1971. Competitive protein-binding radioassay for 25-hydroxycholecalciferol. J. Clin. Endocrinol. Metab. 33 : 992.

32. Fraser, D. R., and E. Kodicek. 1970. Unique biosynthesis by kidney of a biologically active vitamin D metabolite. Nature (London). 228: 764.

33. Kuntzman, R., M. Jacobson, W. Levin, and A. H. Conney. 1968. Stimulatory effect of $n$-phenylbarbital (phetharbital) on cortisol hydroxylation in man. Biochem. Pharmacol. 17: 565.

34. Conney, A. H. 1967. Pharmacological implications of microsomal enzyme induction. Pharmacol. Rev. 19: 317. 